\title{
Impacts of the photo-driven post-depositional processing on snow nitrate and its isotopes at Summit, Greenland: a model-based study
}

\author{
Zhuang Jiang ${ }^{1}$, Becky Alexander ${ }^{2}$, Joel Savarino ${ }^{3}$, Joseph Erbland ${ }^{3}$, and Lei Geng St,4,6 $^{1,5}$ \\ ${ }^{1}$ Anhui Province Key Laboratory of Polar Environment and Global Change, School of Earth and Space Sciences, \\ University of Science and Technology of China, Hefei, Anhui, China \\ ${ }^{2}$ Department of Atmospheric Sciences, University of Washington, Seattle, WA, USA \\ ${ }^{3}$ Univ. Grenoble Alpes, CNRS, IRD, G-INP, Institut des Géosciences de l'Environnement, \\ Grenoble, France \\ ${ }^{4}$ Qingdao National Laboratory for Marine Science and Technology, Qingdao, China \\ ${ }^{5}$ CAS Center for Excellence in Comparative Planetology, University of Science and Technology of China, \\ Hefei, Anhui, China \\ ${ }^{6}$ Hefei National Laboratory for Physical Sciences at the Microscale, University of Science and Technology of China, \\ Hefei, Anhui, China
}

Correspondence: Lei Geng (genglei@ustc.edu.cn)

Received: 13 March 2021 - Discussion started: 12 April 2021

Revised: 7 August 2021 - Accepted: 9 August 2021 - Published: 3 September 2021

\begin{abstract}
Atmospheric information embedded in ice-core nitrate is disturbed by post-depositional processing. Here we used a layered snow photochemical column model to explicitly investigate the effects of post-depositional processing on snow nitrate and its isotopes $\left(\delta^{15} \mathrm{~N}\right.$ and $\left.\Delta^{17} \mathrm{O}\right)$ at Summit, Greenland, where post-depositional processing was thought to be minimal due to the high snow accumulation rate. We found significant redistribution of nitrate in the upper snowpack through photolysis, and up to $21 \%$ of nitrate was lost and/or redistributed after deposition. The model indicates post-depositional processing can reproduce much of the observed $\delta^{15} \mathrm{~N}$ seasonality, while seasonal variations in $\delta^{15} \mathrm{~N}$ of primary nitrate are needed to reconcile the timing of the lowest seasonal $\delta^{15} \mathrm{~N}$. In contrast, post-depositional processing can only induce less than $2.1 \%$ seasonal $\Delta^{17} \mathrm{O}$ change, much smaller than the observation $(9 \%$ ) that is ultimately determined by seasonal differences in nitrate formation pathway. Despite significant redistribution of snow nitrate in the photic zone and the associated effects on $\delta^{15} \mathrm{~N}$ seasonality, the net annual effect of post-depositional processing is relatively small, suggesting preservation of atmospheric signals at the annual scale under the present Summit conditions. But at longer timescales when large changes in snow accumu-
\end{abstract}

lation rate occur this post-depositional processing could become a major driver of the $\delta^{15} \mathrm{~N}$ variability in ice-core nitrate.

\section{Introduction}

Nitrate $\left(\mathrm{NO}_{3}^{-}\right)$is one of the most abundant and commonly measured species in ice cores. One of the major subjects of ice-core nitrate studies involves its oxygen isotope mass-independent fractionation signal $\left(\Delta^{17} \mathrm{O}=\delta^{18} \mathrm{O}-\right.$ $0.52 \times \delta^{17} \mathrm{O}$ ), which is a proxy of atmospheric oxidation capacity (Alexander and Mickley, 2015; Alexander et al., 2004; Geng et al., 2017). Ice-core $\delta^{15} \mathrm{~N}\left(\mathrm{NO}_{3}^{-}\right)$records have also been studied, but the interpretation remains immature and sometimes conflicting (Freyer et al., 1996; Geng et al., 2014a, 2015; Hasting et al., 2005, 2009). There are many factors, e.g., $\mathrm{NO}_{x}$ sources, atmospheric chemistry and transport, deposition, and post-depositional processing of nitrate, affecting ice-core nitrate and its isotopes (Geng et al., 2014a, 2015; Hastings et al., 2004, 2005; Morin et al., 2008; Wolff et al., 2008).

Deposition of atmospheric nitrate to snow is not irreversible. The ultimate source of snow nitrate in the polar regions is from tropospheric long-range transport and strato- 
spheric denitrification (Goto-Azuma and Koerner, 2001; Legrand and Delmas, 1986), which can be termed as primary nitrate $\left(F_{\text {pri }}\right)$ (Erbland et al., 2013). After deposition, nitrate undergoes post-depositional processing which causes changes in its concentration and isotopes (Blunier et al., 2005; Erbland et al., 2013; Frey et al., 2009). Postdepositional processing of snow nitrate includes physical release (i.e., desorption and evaporation) and ultraviolet photolysis. Both processes result in loss of snow nitrate and isotope fractionations of nitrogen and oxygen. However, laboratory experiments and model calculations indicate a minor influence of the physical processes, with photolysis dominating post-depositional processing (Berhanu et al., 2014; Erbland et al., 2013; Frey et al., 2009; Zatko et al., 2016).

Snow nitrate photolysis occurs when it is exposed to sunlight at wavelengths less than $345 \mathrm{~nm}$ (Chu and Anastasio, 2003). The dominant photolysis product is $\mathrm{NO}_{2}$, which is effectively transported to the overlying atmosphere via diffusion or wind pumping (Zatko et al., 2013) and impacts the local atmospheric oxidation environment (Thomas et al., 2012). The released $\mathrm{NO}_{2}$ can reform $\mathrm{HNO}_{3}$ (i.e., the snow-sourced nitrate hereafter) in the overlaying atmosphere, which is then redeposited to or exported from the site of photolysis. The above-mentioned processes form a cycle of nitrate between the air-snow interface, resulting in the redistribution of nitrate in snowpack.

The photolysis also causes isotope fractionation. The isotope fractionation factors $\left(\varepsilon_{\mathrm{p}}\right)$ associated with snow nitrate photolysis are $-47.9 \pm 6.8 \%$ and $-34 \%$ for $\delta^{15} \mathrm{~N}$ and $\delta^{18} \mathrm{O}$, respectively, for local conditions at Dome C, East Antarctica (Berhanu et al., 2014; Blunier et al., 2005; Frey et al., 2009). These large negative values indicate the photolysis would enrich nitrate remaining in snow with heavier isotopes (i.e., ${ }^{15} \mathrm{~N}$ and $\left.{ }^{18} \mathrm{O}\right)$. In comparison, $\Delta^{17} \mathrm{O}\left(\mathrm{NO}_{3}^{-}\right)$in snow will not be directly disturbed by photolysis. However, part of the photoproduct can undergo recombination reactions within snow grains to reform nitrate (i.e., the cage effect) (McCabe et al., 2005; Meusinger et al., 2014). This process results in exchanges in oxygen atoms with snow and decreasing $\Delta^{17} \mathrm{O}\left(\mathrm{NO}_{3}^{-}\right)$and $\delta^{18} \mathrm{O}\left(\mathrm{NO}_{3}^{-}\right)$. In addition, once the photoproduct $\mathrm{NO}_{2}$ is released to the overlying atmosphere, it is rapidly converted to nitrate and carries different $\Delta^{17} \mathrm{O}\left(\mathrm{NO}_{3}^{-}\right)$values from its precursors. These isotope effects have been documented in multiple snowpack studies on the East Antarctic Plateau, with increasing $\delta^{15} \mathrm{~N}$ and decreasing $\Delta^{17} \mathrm{O}\left(\mathrm{NO}_{3}^{-}\right) / \delta^{18} \mathrm{O}\left(\mathrm{NO}_{3}^{-}\right)$with depth (Erbland et al., 2013; Frey et al., 2009; Shi et al., 2015).

The degree of post-depositional processing and the induced effects on snow nitrate and isotopes vary site by site, depending on several factors including actinic flux, snow properties (e.g., density, light-absorbing impurities, specific surface area) and snow accumulation rate (Zatko et al., 2013). Actinic flux describes the light intensity reaching the snow surface, while snow properties determine the penetration of light in snow. Actinic flux decreases exponentially from the snow surface, and the depth of the snow photic zone is defined as 3 times the e-folding depth of the actinic flux (Erbland et al., 2013). Snow accumulation rate determines the residence time of nitrate in the photic zone where photolysis occurs, and thus at sites with high snow accumulation rate the degree of post-depositional processing will be limited (Erbland et al., 2013; Noro et al., 2018; Shi et al., 2015).

Summit, Greenland, is a typical high snow accumulation site $\left(250 \mathrm{~kg} \mathrm{~m}^{-2} \mathrm{a}^{-1}\right.$; Dibb and Fahnestock, 2004), where snowpack and ice-core nitrate isotope records have been studied, but the interpretation of $\delta^{15} \mathrm{~N}$ remains conflicting (Geng et al., 2014a, 2015; Hastings et al., 2005, 2009). Hastings et al. (2005) proposed the glacial-interglacial $\delta^{15} \mathrm{~N}$ difference observed in the GISP2 ice core was due to changes in $\mathrm{NO}_{x}$ source strengths despite the fact that there is no known $\mathrm{NO}_{x}$ source carrying high enough $\delta^{15} \mathrm{~N}$ to explain the glacial $\delta^{15} \mathrm{~N}$ value $(28.4 \pm 1.1 \%$ ). In contrast, Geng et al. (2015) concluded that changes in the degree of post-depositional processing between the glacial and interglacial climates can explain the more enriched $\delta^{15} \mathrm{~N}$ in the glacial period. On seasonal timescales, there are also distinct variations in nitrate $\delta^{15} \mathrm{~N}$ and $\Delta^{17} \mathrm{O}$ at Summit (Geng et al., 2014b; Hastings et al., 2004; Jarvis et al., 2009; Kunasek et al., 2008). The seasonality of $\delta^{15} \mathrm{~N}$ was originally attributed to variations in $\mathrm{NO}_{x}$ sources (Hastings et al., 2004), and the $\Delta^{17} \mathrm{O}$ was suggested to be mainly caused by changes in atmospheric nitrate formation pathways (Kunasek et al., 2008). However, the effect of post-depositional processing on seasonal $\delta^{15} \mathrm{~N}$ variation was not thoughtfully examined by Hastings et al. (2004). Two later studies by Fibiger et al. (2013, 2016) examined nitrate isotopes in the atmosphere and surface snow $(<3 \mathrm{~cm}$ depth $)$ at Summit to investigate the effects of post-depositional processing, and they concluded that the effects of post-depositional processing on nitrate isotope preservation is negligible. These studies, however, relied only on surface snow samples and did not cover a full year of nitrate deposition. The snow photic zone at Summit is 30 to $40 \mathrm{~cm}$ deep (Galbavy et al., 2007), and thus surface snow samples cannot readily reflect the full degree of post-depositional processing as the effects increase with time in the snow photic zone and thus depth. In particular, Fibiger et al. (2013) used the observed linear relationship between surface snow $\Delta^{17} \mathrm{O}\left(\mathrm{NO}_{3}^{-}\right)$and $\delta^{18} \mathrm{O}\left(\mathrm{NO}_{3}^{-}\right)$to exclude the effects of post-depositional processing on nitrate isotopes at Summit, Greenland. This approach is flawed as neither $\delta^{18} \mathrm{O}\left(\mathrm{NO}_{3}^{-}\right)$nor $\Delta^{17} \mathrm{O}\left(\mathrm{NO}_{3}^{-}\right)$is a good indicator of post-depositional processing because the oxygen isotopes are mainly controlled by atmospheric processes (Alexander et al., 2020; Kunasek et al., 2008). This is why a strong linear relationship between $\Delta^{17} \mathrm{O}\left(\mathrm{NO}_{3}^{-}\right)$and $\delta^{18} \mathrm{O}\left(\mathrm{NO}_{3}^{-}\right)$is observed in atmospheric and surface snow samples at Dome $\mathrm{C}$, Antarctica, where severe post-depositional processing of nitrate occurs (Erbland et al., 2013; Frey et al., 2009). At sites with extremely low snow accumulation rates (e.g., Dome C and Dome A in Antarctica) the cage effect would cause ap- 
parent changes in $\delta^{18} \mathrm{O}\left(\mathrm{NO}_{3}^{-}\right)$and $\Delta^{17} \mathrm{O}\left(\mathrm{NO}_{3}^{-}\right)$in samples at depth but not at the surface (Erbland et al., 2013; Shi et al., 2015).

Given the distinct seasonal differences in actinic flux in the polar regions including Summit, Greenland, seasonal differences in the degree of post-depositional processing and its effects on snow nitrate isotopes should be examined. In fact, observations at Summit indicate that $\delta^{15} \mathrm{~N}$ in surface snow nitrate is negative during most of the year with an annual mean of $-6.2 \pm 1.1 \%$ (Jarvis et al., 2009), while in bulk snowpack ( 0 to $1 \mathrm{~m}$ ) the annual mean $\delta^{15} \mathrm{~N}$ is $0 \pm 2.4 \%$ o (Jarvis et al., 2009) and $0 \pm 6.3 \%$ (Geng et al., 2014b). During spring and summer when snow photochemistry is most active, $\delta^{15} \mathrm{~N}$ in surface snow is $-5.8 \pm 0.7 \%$, while in snowpack (average of two springs at depths of 0.15 and $0.9 \mathrm{~m}$ ) is $5.6 \pm 1.8 \%$. These differences between nitrate at the surface and at depth suggest enrichment in nitrate $\delta^{15} \mathrm{~N}$ after deposition and recycling at the surface, and they are consistent with the known isotope effects of post-depositional processing. In addition, Burkhart et al. (2004) and Dibb et al. (2007) have observed $<7 \%$ to $25 \%$ loss of nitrate after deposition at Summit. This is close to the estimate of $16 \%-23 \%$ loss based on ice-core $\delta^{15} \mathrm{~N}\left(\mathrm{NO}_{3}^{-}\right)$(Geng et al., 2015). These results are also qualitatively consistent with the observations of $\mathrm{NO}_{2}$ and $\mathrm{HONO}$ fluxes from snowpack at Summit which were attributed to snow nitrate photolysis (Dibb et al., 2002; Honrath et al., 2002). The spatial variations in the photodriven nitrate recycling at the air-snow interface and its impact on snow $\delta^{15} \mathrm{~N}\left(\mathrm{NO}_{3}^{-}\right)$in Greenland have been studied by Zatko et al. (2016) using a global 3-D chemical transport model (GEOS-Chem). Their model captures the increasing trend in snow $\delta^{15} \mathrm{~N}\left(\mathrm{NO}_{3}^{-}\right)$from the coast to inland as snow accumulation rate decreases, which enhances the degree of post-depositional processing. This is consistent with field studies of snow nitrate $\delta^{15} \mathrm{~N}\left(\mathrm{NO}_{3}^{-}\right)$in West Greenland (Curtis et al., 2018). But the model treated snowpack as a whole and did not specify the behaviors of nitrate at different depths in the photic zone, and it cannot distinguish seasonal differences. In addition, it did not incorporate isotope fractionation associated with photolysis but instead using a fixed fractionation constant and a Rayleigh fractionation model to calculate the changes in isotope with mass loss.

In order to investigate the impacts of snow nitrate photolysis on the preservation of nitrate and its isotopes on the seasonal timescale at Summit, Greenland, we used a snow photochemical column model to simulate the recycling of nitrate at the air-snow interface. We use the model to quantify to what degree the magnitude of the observed seasonality of nitrate isotopes at Summit can be explained by postdepositional processing. The model was built to explicitly investigate the loss of snow nitrate due to photolysis and quantify the induced isotope effects with layer specific calculations (i.e., changes in $\delta^{15} \mathrm{~N}$ and $\Delta^{17} \mathrm{O}$ after deposition). A comparison of the model results with observations should add insight into the preservation of nitrate at high snow accu- mulation sites and shed light on the interpretation of ice-core nitrate and its isotopes.

\section{Model description}

TRANSITS (TRansfer of Atmospheric Nitrate Stable Isotopes To the Snow) is a multi-layer, 1-D model that simulates nitrate recycling at the air-snow interface and its preservation in snow including its isotopes (Erbland et al., 2015). The model divides a year into 52 time steps (i.e., weekly resolution), and at each step the snowpack is divided into $1 \mathrm{~mm}$ layers in which photolysis of nitrate is calculated according to the depth-dependent actinic flux and nitrate concentration. The produced $\mathrm{NO}_{2}$ is transported to the overlying atmosphere where it is re-oxidized to nitrate. At the next time step, a portion of the reformed nitrate together with primary nitrate originating from long-range transport is deposited onto the snow surface. When snowfall occurs, the snowpack moves down, and the newly deposited snow is immediately re-divided into $1 \mathrm{~mm}$ layers. Nitrate is considered as archived once it is buried below the photic zone.

At each step, the model also calculates the isotope effects. In the model, nitrogen isotope fractionation mainly occurs during the photolysis with a wavelength-sensitive fractionation constant $\varepsilon_{\mathrm{p}}$, and another fractionation occurs during nitrate deposition with a fractionation constant $\varepsilon_{\mathrm{d}}$. The oxygen isotope effect is only calculated for $\Delta^{17} \mathrm{O}$, which is caused by (1) exchange of oxygen atoms with water during the photolysis (i.e., the cage effect) and (2) local atmospheric NO- $\mathrm{NO}_{2}$ cycling and the subsequent conversion of $\mathrm{NO}_{2}$ to $\mathrm{HNO}_{3}$.

To run the model, actinic flux and its e-folding depth in snowpack, snow accumulation rate, and other atmospheric properties including the boundary layer height, surface ozone and $\mathrm{HO}_{x}$ concentrations are needed. Additional model inputs are the flux of primary nitrate from long-range transport and its isotopic composition (i.e., $\delta^{15} \mathrm{~N}$ and $\Delta^{17} \mathrm{O}$ ). In this study we focus on the seasonal changes in isotopes caused by postdepositional processing, making the results independent of $\delta^{15} \mathrm{~N}$ and $\Delta^{17} \mathrm{O}$ of primary nitrate.

In this study, we run the model from the year 2004 to 2007 constrained by local observations at Summit. The modeled snow nitrate concentration and isotope profiles were compared with observations in Geng et al. (2014b).

\subsection{Model inputs}

\subsubsection{Atmospheric characterizations}

The overlying atmosphere at Summit was assumed to be a 1-D box with a constant boundary layer height of $156 \mathrm{~m}$ (Cohen et al., 2007), where primary and the snow-sourced nitrate are assumed to be well mixed. Weekly air temperature, pressure, surface ozone concentration and total column ozone (TCO) at Summit were obtained from the NOAA ozonesonde dataset (https://gml.noaa.gov/aftp/ozwv/ 
Ozonesonde/, last access: 1 September 2021). Concentrations of local atmospheric oxidants including $\mathrm{O}_{3}, \mathrm{OH}$, peroxyl radicals and $\mathrm{BrO}$ are needed to calculate the cycling of $\mathrm{NO}-\mathrm{NO}_{2}$ and the conversion of $\mathrm{NO}_{2}$ to $\mathrm{HNO}_{3}$. At Summit, there are no long-term observations of $\mathrm{OH}$ and peroxyl radicals $\left(\mathrm{RO}_{2}, \mathrm{HO}_{2}\right)$ which are necessary to calculate the atmospheric transformation of $\mathrm{NO}_{x}$ to $\mathrm{HNO}_{3}$, so we estimated their mixing ratio by assuming a linear relationship with local $J_{\left(\mathrm{NO}_{2}\right)}$. More specifically, the photolysis rate constants of $\mathrm{NO}_{2}$ were first calculated using local actinic flux, and the concentrations of $\mathrm{OH}$ and peroxyl radicals were calculated by assuming their linear relationships with $J_{\left(\mathrm{NO}_{2}\right)}$ (Kukui et al., 2014). Diurnal observations of OH and peroxyl radicals exist at Summit with noon values of $6.3 \times 10^{6}$ and $2.4 \times 10^{8}$ molec. $\mathrm{cm}^{-3}$ (Sjostedt et al., 2007), respectively. We used these values to justify the calculated $\mathrm{OH}$ and peroxyl radical values by applying scaling factors to match them with the observations. We set a constant $\mathrm{BrO}$ concentration of 2 pptv (parts per trillion volume) in summer and zero in other seasons, given the observed summer $\mathrm{BrO}$ concentration (1-3 pptv) at Summit (Fibiger et al., 2016).

The mass balance of nitrate in snowpack and the overlying atmosphere is controlled by nitrate flux in and out of the snow. We denote the nitrate fluxes as "FY" following Erbland et al. (2015), with $F_{\text {pri, }}, \mathrm{FP}, \mathrm{FD}$ and FA representing the primary nitrate flux from long-range transport, the nitrate flux that originates from photolysis of snow nitrate, the deposition flux (FD) of atmospheric nitrate and the archived snow nitrate flux that is buried under the photic zone, respectively. These fluxes determine the variations in snow and atmospheric nitrate and their isotope compositions.

\subsubsection{Radiative transfer and nitrate photolysis rate in snow}

Downward/upward actinic flux spectrum at the snow surface was calculated using the Troposphere Ultraviolet and Visible (TUV) radiation model (Madronich et al., 1998) constrained by TCO. Radiative transfer inside the snowpack was then computed using the Two-stream Analytical Radiative TransfEr in Snow (TARTES) model (Libois et al., 2013). The attenuation of light in snow is characterized by its e-folding depth, which represents the depth where radiation decreases to $1 / e$ of the surface intensity. Snow e-folding depth depends on its optical properties (e.g., bulk density, snow grain size) and on the concentrations of light-absorbing impurities (Zatko et al., 2013). In this study, for simplification, we set constant snowpack concentrations of the three main snow lightabsorbing impurities - soot, dust and organic humic-like substance (HULIS) - at 1.4, 138 and $31 \mathrm{ng} \mathrm{g}^{-1}$, respectively (Zatko et al., 2013; Carmagnola et al., 2013). Snow density and grain size also impact the e-folding depth. The snow radiation equivalent mean grain radius $\left(r_{\mathrm{e}}\right)$ is linked to the specific surface area (SSA) of snow grains by $r_{\mathrm{e}}=3 /\left(\mathrm{SSA} \times \rho_{\text {ice }}\right)$. Since direct observations of SSA of the reported snowpack in Geng et al. (2004b) are lacking and only density profile data exist, we used the regression relationship between SSA and $\rho_{\text {snow }}\left(\mathrm{SSA}=-174.13 \times \ln \left(\rho_{\text {snow }}\right)+306.4\right.$, in units of $\mathrm{cm}^{2} \mathrm{~g}^{-1}$ for SSA and $\mathrm{g} \mathrm{cm}^{-3}$ for density) from Domine et al. (2007) to calculate SSA. Using the observed snow density, fixed light-absorbing impurity concentrations and the calculated SSA profile, we obtained an e-folding depth of $12.3 \mathrm{~cm}$ (at a wavelength of $305 \mathrm{~nm}$, which is the peak wavelength of nitrate photolysis) that is similar to the measured average summer midday value $(11.6 \mathrm{~cm})$ at Summit (Galbavy et al., 2007) but lower than the modeled result $(15-17 \mathrm{~cm})$ by Zatko et al. (2013). Note Zatko et al. (2013) applied the measured snow $r_{\mathrm{e}}$ profile at Dome $\mathrm{C}$ to Summit conditions with SSA ranging from 7 to $38 \mathrm{~m}^{2} \mathrm{~kg}^{-1}$, which was lower than our calculated SSA of 44 to $51 \mathrm{~m}^{2} \mathrm{~kg}^{-1}$. This likely explains why our calculated e-folding depth was smaller than Zatko et al. (2013) despite using the same impurity content. We also note that the regression relationship between SSA and $\rho$ snow from Domine et al. (2007) was for fresh snow, which may not be suitable for SSA prediction for the whole snowpack. However, using this equation yielded an e-folding depth that is similar to the observations by Galbavy et al. (2007) despite the yielded SSA appearing to be larger than the observed values ( 20 to $40 \mathrm{~m}^{2} \mathrm{~kg}^{-1}$ ) by Carmagnola et al. (2013) for a Summit snowpack which has a much lower snow density (averaged $330 \mathrm{~kg} \mathrm{~m}^{-3}$ in the top $50 \mathrm{~cm}$ ) than ours (averaged $395 \mathrm{~kg} \mathrm{~m}^{-3}$ ). Nevertheless, given the uncertainties related to the calculation of snow radiative transfer that are currently not well constrained, the regression relationship between SSA and $\rho$ snow used here yielded a reasonable e-folding depth similar to the observations. Improvements can be made if snow physicochemical properties (e.g., SSA, density and impurity concentrations) can be precisely well constrained by future observations.

The photolysis rate constant of snow $\mathrm{NO}_{3}^{-}$was calculated by the following:

$$
J(z)=\int_{280 \mathrm{~nm}}^{350 \mathrm{~nm}} \Phi(\lambda) \times \sigma_{\mathrm{NO}_{3}^{-}}(\lambda) \times I(z, \lambda) \mathrm{d} \lambda,
$$

where $I$ is actinic flux, and $\Phi$ and $\sigma$ are the quantum yield and absorption cross section of nitrate photolysis, respectively. The absorption cross sections of ${ }^{14} \mathrm{NO}_{3}^{-}$and ${ }^{15} \mathrm{NO}_{3}^{-}$ were from Berhanu et al. (2014). In this study, we used the measured surface snow nitrate photolysis rate constant $j_{0}\left(\mathrm{NO}_{3}^{-}\right)$(Galbavy et al., 2007) to constrain the quantum yield at Summit. Galbavy et al. (2007) reported that $j_{0}\left(\mathrm{NO}_{3}^{-}\right)$ in surface snow at summer noon generally falls in the range of $1-2 \times 10^{-7} \mathrm{~s}^{-1}$ with a mean value of $1.1 \times 10^{-7} \mathrm{~s}^{-1}$. This value corresponds to a quantum yield of 0.002 given typical Summit summer column ozone density (350 DU) and noon solar zenith angle $\left(50^{\circ}\right)$. We adopted this value of quantum yield in our model, and, according to summer actinic flux, its penetration in snowpack and snow nitrate concentration 
at Summit, we calculated a summer mean $\mathrm{NO}_{x}$ flux from the snowpack of $2.96 \pm 0.3 \times 10^{12}$ molec. $\mathrm{m}^{-2} \mathrm{~s}^{-1}$ that is close to the observation of $2.52 \times 10^{12}$ molec. $\mathrm{m}^{-2} \mathrm{~s}^{-1}$ by Honrath et al. (2002).

\subsubsection{Flux of primary nitrate $\left(F_{\text {pri }}\right)$ and the export fraction}

Primary nitrate from long-range transport was assumed to be the only external nitrate source for Summit. Given the mean snow accumulation rate $\left(250 \mathrm{~kg} \mathrm{~m}^{-2} \mathrm{a}^{-1}\right)$ and the mean snowpack nitrate concentration $\left(117 \mathrm{ngg}^{-1}\right)$ at Summit, a minimum annual $F_{\text {pri }}$ of $6.6 \times 10^{-6} \mathrm{~kg} \mathrm{Nm}^{2} \mathrm{a}^{-1}$ was estimated and used in the model. This value is at the same order of magnitude $\left(\approx 2 \times 10^{-6} \mathrm{~kg} \mathrm{~N} \mathrm{~m}^{2} \mathrm{a}^{-1}\right)$ as that modeled by Zatko et al. (2016). The seasonal variability in $F_{\text {pri }}$ was adjusted to $1.6 \times 10^{-6}, 2.1 \times 10^{-6}, 1.6 \times 10^{-6}$ and $1.2 \times 10^{-6} \mathrm{~kg} \mathrm{~N} \mathrm{~m}^{-2}$ per season for spring, summer, autumn and winter, respectively, according to back-trajectory analyses and a regional emission inventory (Iizuka et al., 2018). The values and seasonal variations in $\delta^{15} \mathrm{~N}$ and $\Delta^{17} \mathrm{O}$ of $F_{\text {pri }}$ are currently unknown. We set $\delta^{15} \mathrm{~N}$ and $\Delta^{17} \mathrm{O}$ of $F_{\text {pri }}$ at 0 and $30 \%$ (close to their average values in snowpack), respectively, throughout the year. This has the advantage of the model explicitly assessing the effects of the photolysis while excluding other influencing factors. In addition, previous studies proposed $\delta^{15} \mathrm{~N}$ of snow nitrate at Summit should reflect $\delta^{15} \mathrm{~N}$ of $\mathrm{NO}_{x}$ sources (Hasting el al., 2004, 2005); thus, in order to investigate the sensitivity of snowpack $\delta^{15} \mathrm{~N}\left(\mathrm{NO}_{3}^{-}\right)$to $\delta^{15} \mathrm{~N}$ of $F_{\text {pri }}$, we also used the measured $\delta^{15} \mathrm{~N}$ in surface snow nitrate at Summit that varies seasonally (Jarvis et al., 2009) as a first-order estimation of $\delta^{15} \mathrm{~N}$ of $F_{\text {pri }}$. Note this may underestimate $\delta^{15} \mathrm{~N}$ of $F_{\text {pri }}$ as surface snow nitrate could be influenced by snow-sourced nitrate that is in general depleted of $\delta^{15} \mathrm{~N}$. Nevertheless, we note that $\delta^{15} \mathrm{~N}$ and $\Delta^{17} \mathrm{O}$ of $F_{\text {pri }}$ are just starting points to run the model, and the predicted changes caused by post-depositional processing are independent of these values.

Another parameter influencing the preservation of nitrate is the export fraction, $f_{\exp }$, which represents the fraction of the snow-sourced $\mathrm{NO}_{x}$ and nitrate transported away from the site of photolysis. At the site of photolysis, part of the reformed nitrate in the atmosphere will be exported, and this represents the net loss of nitrate through the post-depositional processing. We estimated the export fraction $\left(f_{\exp }\right)$ following the method used by Erbland et al. (2015):

$f_{\exp }=\frac{\frac{1}{\tau_{2}}}{\frac{1}{\tau_{1}}+\frac{1}{\tau_{2}}} \times\left(1+\frac{\frac{1}{\tau_{1}}}{\frac{1}{\tau_{3}}+\frac{1}{\tau_{1}}}\right)$,

where $\tau_{1}, \tau_{2}$ and $\tau_{3}$ denote the lifetimes of horizontal transport, oxidation of $\mathrm{NO}_{2}$ by $\mathrm{OH}$ radicals and vertical deposition, respectively. $\tau_{1}, \tau_{2}$ and $\tau_{3}$ were calculated as follows:

$\tau_{1}=\frac{L}{v_{\mathrm{h}}}$,

$$
\begin{aligned}
\tau_{2} & =\frac{1}{k[\mathrm{OH}]}, \\
\tau_{3} & =\frac{H}{v_{\mathrm{d}}},
\end{aligned}
$$

where $H$ and $L$ represent the vertical and horizontal characteristic dimensions of $156 \mathrm{~m}$ (average summer boundary layer height at Summit) and $350 \mathrm{~km}$ (characteristic length of summit of the Greenland ice cap; Honrath et al., 2002), respectively, $v_{\mathrm{h}}$ is the mean horizontal wind speed at Summit $\left(5 \mathrm{~m} \mathrm{~s}^{-1}\right), v_{\mathrm{d}}$ is the dry deposition velocity of $\mathrm{HNO}_{3}$ $\left(0.63 \mathrm{~cm} \mathrm{~s}^{-1}\right)$ (Björkman et al., 2013), and $k$ is the kinetic rate constant as a function of temperature and pressure for $\mathrm{NO}_{2}+\mathrm{OH} \rightarrow \mathrm{HNO}_{3}\left(3 \times 10^{-12} \mathrm{~cm}^{3}\right.$ molec. ${ }^{-1} \mathrm{~s}^{-1}$ on average in summer; Atkinson et al., 2004). From Eq. (2) we obtained a value of 0.35 for $f_{\text {exp }}$ in summer conditions and kept it constant in the model simulations. Note this value is irrelevant in winter when photolysis stops; therefore, there is no need to consider the seasonal difference of $f_{\text {exp }}$. In addition, we note the $f_{\exp }$ calculated from the above equations is just a rough estimate as it may oversimplify the processes governing nitrate deposition and chemical loss pathways of $\mathrm{NO}_{x}$. The sensitivity of model results to $f_{\exp }$ is discussed in Sect. 3.3.

\subsection{Calculation of the isotope effects}

The nitrogen isotope fractionation constant $\left({ }^{15} \varepsilon_{\mathrm{p}}\right)$ during photolysis was calculated from the ratio of ${ }^{14} \mathrm{NO}_{3}^{-}$ and ${ }^{15} \mathrm{NO}_{3}^{-}$photolysis rates in each snow layer $\left({ }^{15} \varepsilon_{\mathrm{p}}=\right.$ $\left.J^{15} / J^{14}-1\right)$. The deposition of atmosphere nitrate can induce isotope fractionation $\left(\varepsilon_{\mathrm{d}}\right)$ in $\delta^{15} \mathrm{~N}$ based on simultaneous measurements of atmospheric and surface $\delta^{15} \mathrm{~N}\left(\mathrm{NO}_{3}^{-}\right)$ (Erbland et al., 2013; Fibiger et al., 2016). Fibiger et al. (2016) suggested that at Summit the fresh snow $\mathrm{NO}_{3}^{-}$is enriched in $\delta^{15} \mathrm{~N}$ by $+13 \%$ o compared to atmospheric $\mathrm{NO}_{3}^{-}$, similar to the observation at Dome C, Antarctica $(+10 \%$, Erbland et al., 2013). In contrast, Jarvis et al. (2009) found no difference in $\delta^{15} \mathrm{~N}$ of gas-phase $\mathrm{HNO}_{3}$ and surface snow $\mathrm{NO}_{3}^{-}$at Summit. Here we followed Erbland et al. (2013) to set $\varepsilon_{\mathrm{d}}$ at $+10 \%$. We did not use the results from Fibiger et al. (2013) whose study was conducted in spring when photolysis of snow nitrate had already started and disturbed the connection between atmospheric nitrate and that in surface snow. For oxygen isotopes, the $\Delta^{17} \mathrm{O}$ of the reformed nitrate in the air was assumed to be $2 / 3$ of $\Delta^{17} \mathrm{O}\left(\mathrm{NO}_{2}\right)$, which assumes that $\mathrm{NO}_{2}+\mathrm{OH}$ is the dominant nitrate production mechanism under sunlight. $\Delta{ }^{17} \mathrm{O}\left(\mathrm{NO}_{2}\right)$ was estimated according to the relative importance of $\mathrm{O}_{3}$ and $\mathrm{BrO}$ versus $\mathrm{HO}_{2}$ and $\mathrm{RO}_{2}$ oxidation of $\mathrm{NO}$ to $\mathrm{NO}_{2}$. The $\Delta^{17} \mathrm{O}$ value of bulk $\mathrm{O}_{3}$ is taken at $26 \%$ (Vicars and Savarino, 2014), that of $\mathrm{BrO}$ is $39 \%$, and other oxidants are $0 \%$. We assumed a cage effect of $15 \%$ following Erbland et al. (2015). 


\subsection{Model initiation}

The model was initiated by deposition of primary nitrate mixed with snow-sourced nitrate. A real snowpack with a depth of $2.1 \mathrm{~m}$ and known nitrate concentration and isotope profiles (Geng et al., 2014b) was set at time $(t)=0$. Weekly snow accumulation rate was obtained by averaging the observed snow accumulation of the same week (week 1 to week 52) of a year over 2003 to 2007 at Summit. Average instead of real accumulation data were used to avoid negative values in some weeks due to wind blowing which causes net loss instead of gain of snow. After a 3-year simulation, the snow nitrate concentration and isotope profiles above the preexisting snowpack were sampled from the model to compare with the observations from Geng et al. (2014b). All parameters needed to run the model are listed in Table S1.

\section{Results and discussion}

\subsection{The simulated snowpack nitrate depth profiles at Summit, Greenland}

The observed and modeled snowpack nitrate concentration and its isotopes (i.e., $\delta^{15} \mathrm{~N}$ and $\Delta^{17} \mathrm{O}$ ) from July 2004 to 2007 are plotted in Fig. 1. The observations were from a snow pit collected in July 2007 so that the top of the observed profiles represents a summer, and we used the observed $\Delta^{17} \mathrm{O}$ minimum and concentration maximum to identify other summers to match the modeled profiles with the observations. In addition, the depth of the modeled snowpack was adjusted according to the difference in fresh snow density and the measured snow density profile in the upper $2 \mathrm{~m}$ at Summit (Geng et al., 2014b).

As shown in Fig. 1, nitrate concentrations and isotopes in the modeled snowpack in general display similar seasonal patterns to the observations except for $\Delta^{17} \mathrm{O}$ whose magnitude of seasonal change is much smaller than the observations. The modeled average $\mathrm{NO}_{3}^{-}$concentration was $115 \pm 65 \mathrm{ng} \mathrm{g}^{-1}$, similar to the observation of $117 \pm 62 \mathrm{ngg}^{-1}$. The modeled concentration profile displays high variability which is mainly caused by variations in weekly snow accumulation. The modeled results indicate clear summer peaks and winter valleys similar to the observations. In addition, we found with or without seasonal variations in $F_{\text {pri }}$ that the modeled concentration and isotope profiles were almost identical.

The modeled $\Delta^{17} \mathrm{O}\left(\mathrm{NO}_{3}^{-}\right)$deviated by about $2.1 \%$ from primary nitrate $\left(\Delta^{17} \mathrm{O}\left(\mathrm{NO}_{3}^{-}\right)=30 \%\right.$ o $)$ in summer. This is consistent with expectations as post-depositional processing will not cause mass-independent fractionation, so it has no direct effects on $\Delta^{17} \mathrm{O}$. The model deviation is mainly caused by the reformation of nitrate in the local atmosphere which leads to nitrate with different $\Delta^{17} \mathrm{O}$ from primary nitrate. In summer, nitrate reformed in the overlying atmo- sphere occurs mainly through $\mathrm{OH}$ oxidation of $\mathrm{NO}_{2}$. In the model, nitrate formed through this process possessed $\Delta^{17} \mathrm{O}$ of $19.6 \pm 0.3 \%$ on average. This value is close to the modeled results $(18.9 \%$ ) for summer at Summit by Kunasek et al. (2008) who used a box model and assumed local $\mathrm{NO}_{x}$ chemistry is the only nitrate source. $\Delta^{17} \mathrm{O}$ of nitrate formed from local chemistry is lower than that in summer snow $(\sim 25 \%$ ) , and this could be related to transport of external nitrate as suggested by Kunasek et al. (2008). Indeed, unlike in summer conditions at Summit, nitrate transported from outside of the Arctic would be formed by both nightand daytime reactions and should possess higher $\Delta^{17} \mathrm{O}$ than locally formed nitrate which is mainly from $\mathrm{OH}$ oxidation (Kunasek et al., 2008). In our model, the $\Delta^{17} \mathrm{O}\left(\mathrm{NO}_{3}^{-}\right)$of $F_{\text {pri }}$ was assumed to be $30 \%$. Although this is unlikely to be the true value of long-range-transported nitrate, it can be viewed as the starting value from which we can assess the effects of post-depositional processing (i.e., the changes caused by post-depositional processing) which is the focus of this study. In the model, the summer-deposited nitrate possesses $\Delta^{17} \mathrm{O}$ that is $1.9 \%$ o lower than that of $F_{\text {pri }}$ due to the mixing of $F_{\text {pri }}$ with snow-sourced nitrate. In wintertime, local nitrate formation in the overlying atmosphere is muted in the model as there is no sunlight, and thus the deposited $\Delta^{17} \mathrm{O}\left(\mathrm{NO}_{3}^{-}\right)$is completely controlled by $\Delta^{17} \mathrm{O}\left(\mathrm{NO}_{3}^{-}\right)$of $F_{\text {pri }}$.

In addition, the cage effect during photolysis further reduces $\Delta{ }^{17} \mathrm{O}$ in snow nitrate by $\sim 0.2 \%$. This is different from what occurs on the East Antarctic Plateau where the cage effect dominates the post-depositional $\Delta^{17} \mathrm{O}\left(\mathrm{NO}_{3}^{-}\right)$decrease (Erbland et al., 2013). This is because on the East Antarctic Plateau, the snow accumulation rate is very low, and nitrate remains in the photic zone for 5 years or longer (compared to less than a year at Summit, Greenland). Taking into account the cage effect in Summit snow, a $2.1 \%$ o $\Delta \Delta^{17} \mathrm{O}$ seasonality was simulated by the model, which is much smaller compared to the observed 9\%o seasonality (Fig. 1c). Note that as our model does not consider nitrate formation via $\mathrm{BrONO}_{2}$ hydrolysis, which tends to produce nitrate with higher $\Delta^{17} \mathrm{O}$ than $\mathrm{OH}$ oxidation, the modeled $2.1 \%$ o seasonality is an upper limit. In all, the results suggest that post-depositional processing does not play a significant role in regulating the observed seasonality of $\Delta^{17} \mathrm{O}\left(\mathrm{NO}_{3}^{-}\right)$at Summit, which is probably mainly caused by seasonal differences in $\Delta^{17} \mathrm{O}\left(\mathrm{NO}_{3}^{-}\right)$of $F_{\text {pri }}$ in addition to seasonal differences in local nitrate formations as suggested by Kunasek et al. (2008).

The observed surface snow $\delta^{15} \mathrm{~N}\left(\mathrm{NO}_{3}^{-}\right)$(green curve in Fig. 1b) varies from $-13.0 \%$ to $-2.8 \%$ in a year (Jarvis et al., 2009). In comparison, observed snowpack $\delta^{15} \mathrm{~N}\left(\mathrm{NO}_{3}^{-}\right)$ varies from $-9.8 \pm 3.1 \%$ of the annual valleys to $6.3 \pm 1.8 \%$ o of the annual peaks (average of 3 years of observations) and displays apparent enrichments in spring and early summer. This difference suggests substantial changes in $\delta^{15} \mathrm{~N}\left(\mathrm{NO}_{3}^{-}\right)$ after deposition. The model with constant $\delta^{15} \mathrm{~N}$ of $F_{\text {pri }}$ (i.e.,

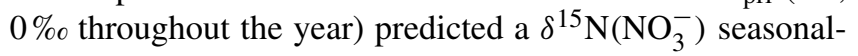




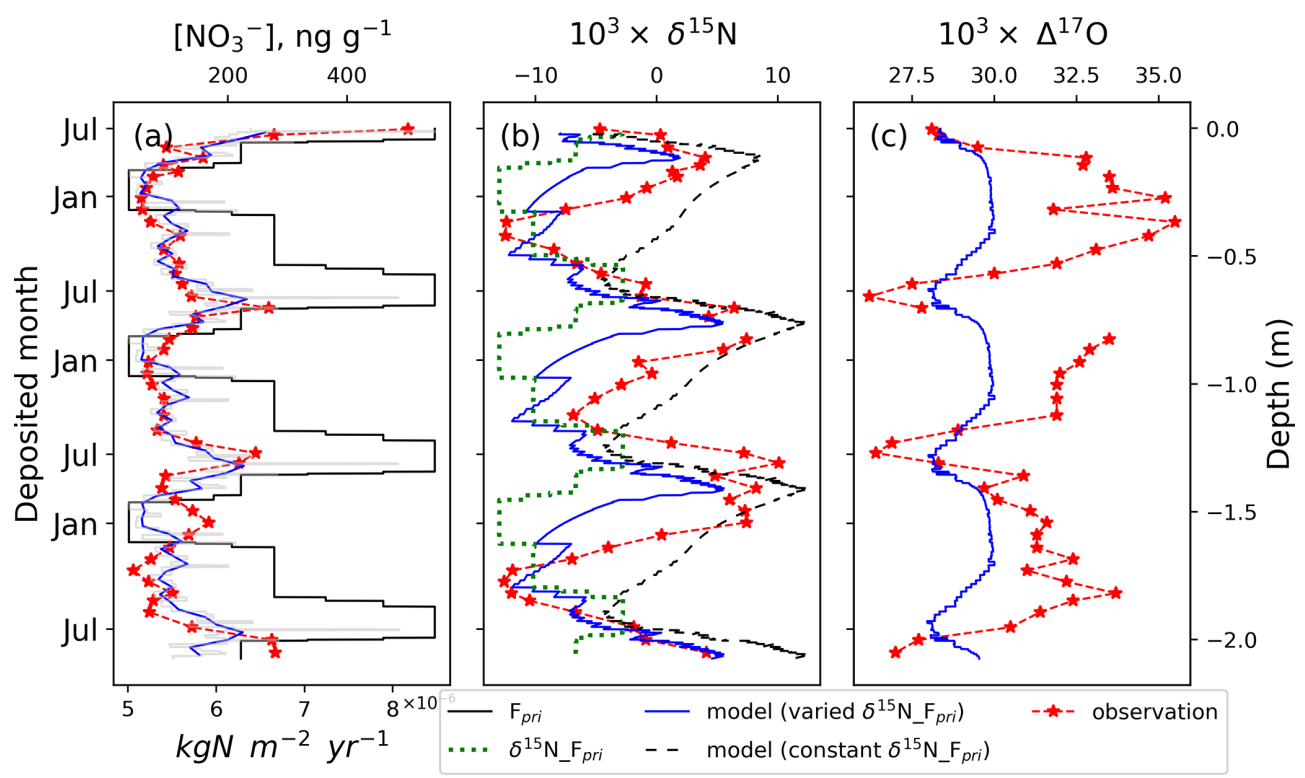

Figure 1. Snowpack nitrate concentration and isotope profiles at Summit, Greenland (red: observations; blue: modeled). The gray curve in (a) is the modeled weekly data, while the blue curve is the monthly average. The dashed green line in (b) represents measured $\delta^{15} \mathrm{~N}$ in surface snow throughout a year (Jarvis et al., 2009). The measured minimum $\Delta^{17} \mathrm{O}\left(\mathrm{NO}_{3}^{-}\right)$was used as the indicator of June-July when local photochemistry is the most active.

ity with a spring peak (dashed black curve in Fig. 2b), and the modeled magnitude of seasonal difference is $\sim 17.5 \%$, which is similar to the observations $(16.1 \pm 3.6 \%$ o seasonality). But there is a constant model-observation discrepancy that the lowest $\delta^{15} \mathrm{~N}\left(\mathrm{NO}_{3}^{-}\right)$value in a year appears earlier in the model than in the observations. When including seasonal variations in $\delta^{15} \mathrm{~N}$ of $F_{\text {pri }}$ (i.e., using year-round surface $\left.\delta^{15} \mathrm{~N}\left(\mathrm{NO}_{3}^{-}\right)\right)$, the modeled seasonal $\delta^{15} \mathrm{~N}\left(\mathrm{NO}_{3}^{-}\right)$pattern, as well as the magnitude $(\sim 18.3 \%$ o) (blue curve in Fig. $1 \mathrm{~b}$ ), became almost identical to the observations except that the absolute values of the modeled $\delta^{15} \mathrm{~N}\left(\mathrm{NO}_{3}^{-}\right)$are on average $5.2 \%$ lower than the observations. This modeled underestimate could be due to the use of observed $\delta^{15} \mathrm{~N}$ of surface snow nitrate $(-6.2 \pm 1.1 \%$ on average) which may underestimate $\delta^{15} \mathrm{~N}$ of $F_{\text {pri }}$. The $\delta^{15} \mathrm{~N}$ of surface snow nitrate is affected by the input of snow-sourced nitrate depleted of $\delta^{15} \mathrm{~N}$ in the summer. Therefore, the modeled snowpack $\delta^{15} \mathrm{~N}$ should be lower than the observation given that the starting values in the model are biased low. In comparison, the simulation with constant $\delta^{15} \mathrm{~N}$ of $F_{\text {pri }}$ (i.e., $0 \%$ ) predicted absolute values generally higher than the observations, which may be because the value of $0 \%$ might be an overestimate.

The occurrence of the spring $\delta^{15} \mathrm{~N}$ peak should be also driven by post-depositional processing. Post-depositional processing starts after polar sunrise and continues to operate until the beginning of polar winter. During this time, the effect of post-depositional processing accumulates, and the spring snow layer has experienced the largest degree of postdepositional loss and thus exhibits the most enriched $\delta^{15} \mathrm{~N}$. The annual snow thickness at Summit is $\sim 65 \pm 10 \mathrm{~cm} \mathrm{a}^{-1}$, which is twice the depth of the photic zone, and therefore there should be no additional post-depositional processing

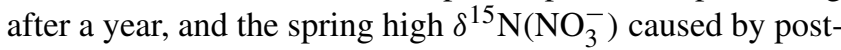
depositional processing is preserved as seen in the model and observations.

\subsection{Seasonality of photolysis flux (FP) and deposition flux (FD)}

To discern the processes leading to the seasonal isotope patterns, we further investigated the weekly nitrate deposition flux (FD) and isotopes, as well as the weekly flux of snow-sourced nitrate (FP) and isotopes, using the model. As shown in Fig. 2a, during mid-summer when actinic flux reaches its maximum, FP reaches the maximum (and is zero in winter). Our simulated average daily $\mathrm{NO}_{2}$ flux from snowpack in summer was $2.96 \times 10^{12}$ molec. $\mathrm{m}^{-2} \mathrm{~s}^{-1}$, in good agreement with summer observations at Summit $\left(2.52 \times 10^{12}\right.$ molec. $\mathrm{m}^{-2} \mathrm{~s}^{-1}$; Honrath et al., 2002). FD is a mixture of $F_{\text {pri }}$ and FP, so it also reaches the maximum in summer due to the contribution of FP, in addition to the summer high $F_{\text {pri }}$. This at least in part explains the modeled summer nitrate concentration maximum. But even in summer, FP was only about $25 \%$ of FD, demonstrating the importance of $F_{\text {pri }}$ in determining the budget of snow nitrate at Summit. 


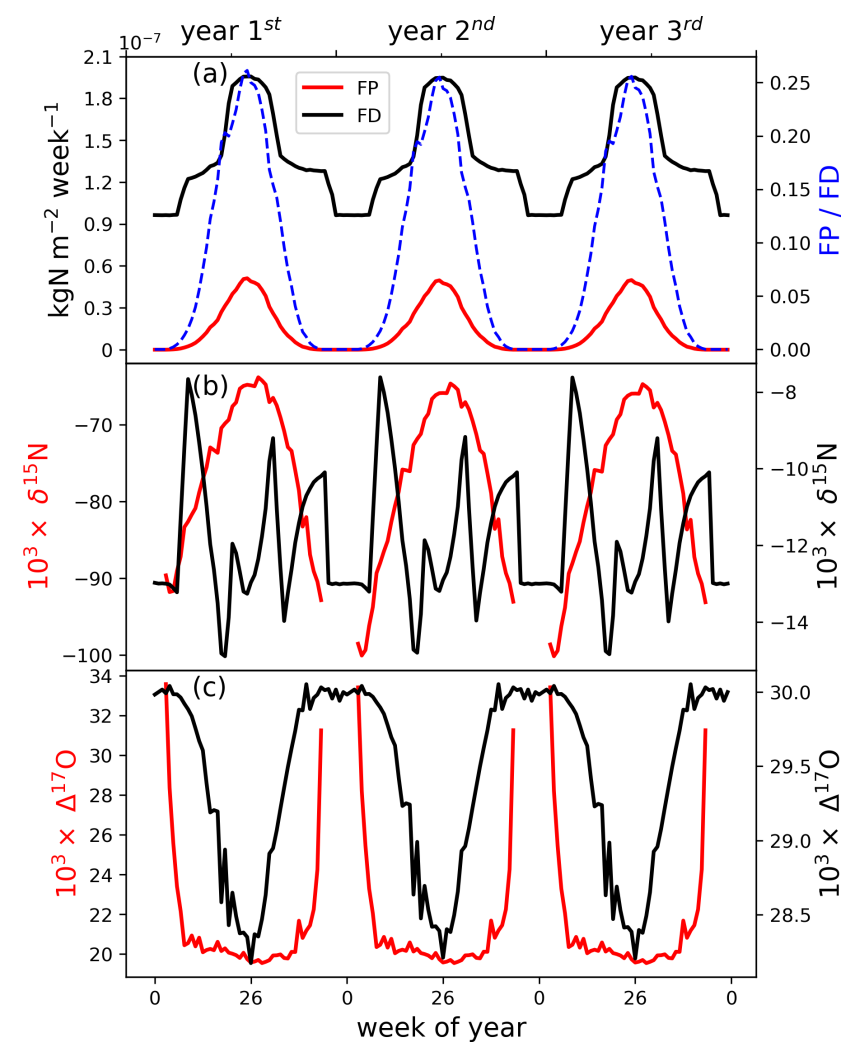

Figure 2. Weekly distribution of photolysis flux (FP) and deposition flux (FD) and their nitrate isotopic compositions. Gaps in FP (red line) are during the winter when there is no sunlight and thus no photolysis. The results shown are those simulated with seasonal variations in the flux and $\delta^{15} \mathrm{~N}$ of primary nitrate $\left(F_{\mathrm{pri}}\right)$.

The $\delta^{15} \mathrm{~N}$ of FP in the half year of summer $(-77 \%$ to $-65 \%$ ) was severely depleted compared to $F_{\text {pri }}(-6.7 \%$ o to $-2.8 \%$ ). As shown in Fig. $2 \mathrm{~b}, \delta^{15} \mathrm{~N}$ of FP gradually increased from the onset of photolysis and reached the highest in mid-summer and decreased after that. This is mainly caused by the wavelength-dependent $\varepsilon_{\mathrm{p}}$ (Berhanu et al., 2014) which varies from $-57 \%$ to $-87 \%$ and peaks in midsummer at Summit (Fig. 3a), corresponding to the smallest isotope effect in mid-summer. The $\delta^{15} \mathrm{~N}\left(\mathrm{NO}_{3}^{-}\right)$of $\mathrm{FD}$ was a combination of FP and $F_{\text {pri }}$. Therefore, a clear decrease in $\delta^{15} \mathrm{~N}\left(\mathrm{NO}_{3}^{-}\right)$of FD can be expected in summer (Fig. 2b) when the contribution of FP was the largest. The isotope effect in $\delta^{15} \mathrm{~N}$ during the deposition of nitrate was also included in the model but turns out to have no apparent impact on the modeled snowpack $\delta^{15} \mathrm{~N}\left(\mathrm{NO}_{3}^{-}\right)$profile. This is because essentially all nitrate in the atmosphere except the fraction being exported was deposited (i.e., FD) over the period of each simulation step (i.e., 1 week), and thus the isotope effects were negligible due to mass balance.

The modeled $\Delta^{17} \mathrm{O}\left(\mathrm{NO}_{3}^{-}\right)$of FP is mainly determined by local atmospheric chemistry, e.g., the $\mathrm{NO}-\mathrm{NO}_{2}$ cycling and the subsequent formation of $\mathrm{HNO}_{3}$. Under the pre- scribed Summit atmospheric conditions, we calculated the $\Delta^{17} \mathrm{O}\left(\mathrm{NO}_{3}^{-}\right)$of FP with a mean of $19.7 \pm 0.3 \%$ during summer. This $\Delta^{17} \mathrm{O}\left(\mathrm{NO}_{3}^{-}\right)$of FP combined with $F_{\text {pri }}\left(\Delta^{17} \mathrm{O}=\right.$ $30 \%$ ), leading to a summer minimum $\Delta^{17} \mathrm{O}$ of FD that was $1.9 \%$ o lower than that of $F_{\text {pri }}$. An additional $\sim 0.2 \%$ difference was induced upon archiving from the cage effect, suggesting the cage effect plays a negligible role in snow $\Delta^{17} \mathrm{O}\left(\mathrm{NO}_{3}^{-}\right)$at Summit. This reinforces why oxygen isotopes should not be used to investigate the degree of postdepositional processing, especially at high snow accumulation sites, because it is dominated by regionally and/or local atmospheric processes.

In addition, our model results indicate apparent recycling of nitrate at the air-snow interface leading to changes in snow nitrate isotopes. This is opposite to Fibiger et al. (2016) who concluded there is little to no local recycling of nitrate at Summit based on the fact that surface snow nitrate $\Delta{ }^{17} \mathrm{O}$ was not elevated when atmospheric $\mathrm{BrO}$ concentration increased. However, high $\mathrm{BrO}$ concentration does not necessarily lead to high atmospheric and/or snow nitrate $\Delta^{17} \mathrm{O}$ for several reasons. First, the production of $\mathrm{BrO}$ will consume $\mathrm{O}_{3}$, and this is a tradeoff in terms of influencing $\Delta^{17} \mathrm{O}\left(\mathrm{NO}_{3}^{-}\right)$. Second, $\mathrm{BrO}$ concentration always covaries with $\mathrm{HO}_{x}\left(\mathrm{HO}_{x}=\mathrm{OH}, \mathrm{RO}_{2}\right.$ and $\left.\mathrm{HO}_{2}\right)$ (Liao et al., 2011), and increases in $\mathrm{HO}_{x}$ tend to lower $\Delta^{17} \mathrm{O}\left(\mathrm{NO}_{3}^{-}\right)$, which offsets the effect of increased $\mathrm{BrO}$ concentration on $\Delta^{17} \mathrm{O}\left(\mathrm{NO}_{3}^{-}\right)$. Third, the $\mathrm{BrO}$ increase observed by Fibiger et al. (2016) only lasted for a few hours, and whether this is long enough to significantly perturb the local atmospheric nitrate budget over longer time periods and nitrate in snow is questionable. Nevertheless, $\mathrm{BrONO}_{2}$ hydrolysis is only one of the many pathways of atmospheric nitrate formation, and for atmospheric nitrate to perturb the surface snow nitrate budget (in the top $2 \mathrm{~cm}$, the observations of Fibiger et al., 2016) through dry deposition, it will need days to weeks of nitrate deposition given its dry deposition flux $(7.16 \times$ $10^{11}$ molec. $\mathrm{m}^{-2} \mathrm{~s}^{-1}$ ) at Summit (Honrath et al., 2002). A chemical transport model with the post-depositional processing incorporated would be best to investigate this further but is out of the scope of this study.

\subsection{Loss of snow nitrate due to photolysis at Summit}

The lost fraction ( $\left.f_{\text {loss }}\right)$ of snow nitrate upon archiving is plotted in Fig. 3a, calculated as the difference in nitrate concentration of an archived layer to the concentration when it was at the surface. As shown in Fig. 3a, throughout a year, $f_{\text {loss }}$ varied from $1.9 \%$ to $21.1 \%$, similar to the $<7 \%$ to $25 \%$ loss estimated by Burkhart et al. (2004) and Dibb et al. (2007). In particular, Dibb et al. (2007) calculated the average $\mathrm{NO}_{3}^{-}$concentrations in fresh and buried snow layers and found a mean of $\sim 9 \%$ loss which is in good agreement with our calculated mean $f_{\text {loss }}$ of $10.4 \pm 6.6 \%$. The loss of nitrate in a snow layer corresponds to the enrichment of $\delta^{15} \mathrm{~N}\left(\mathrm{NO}_{3}^{-}\right)$in that layer. Here we defined the en- 


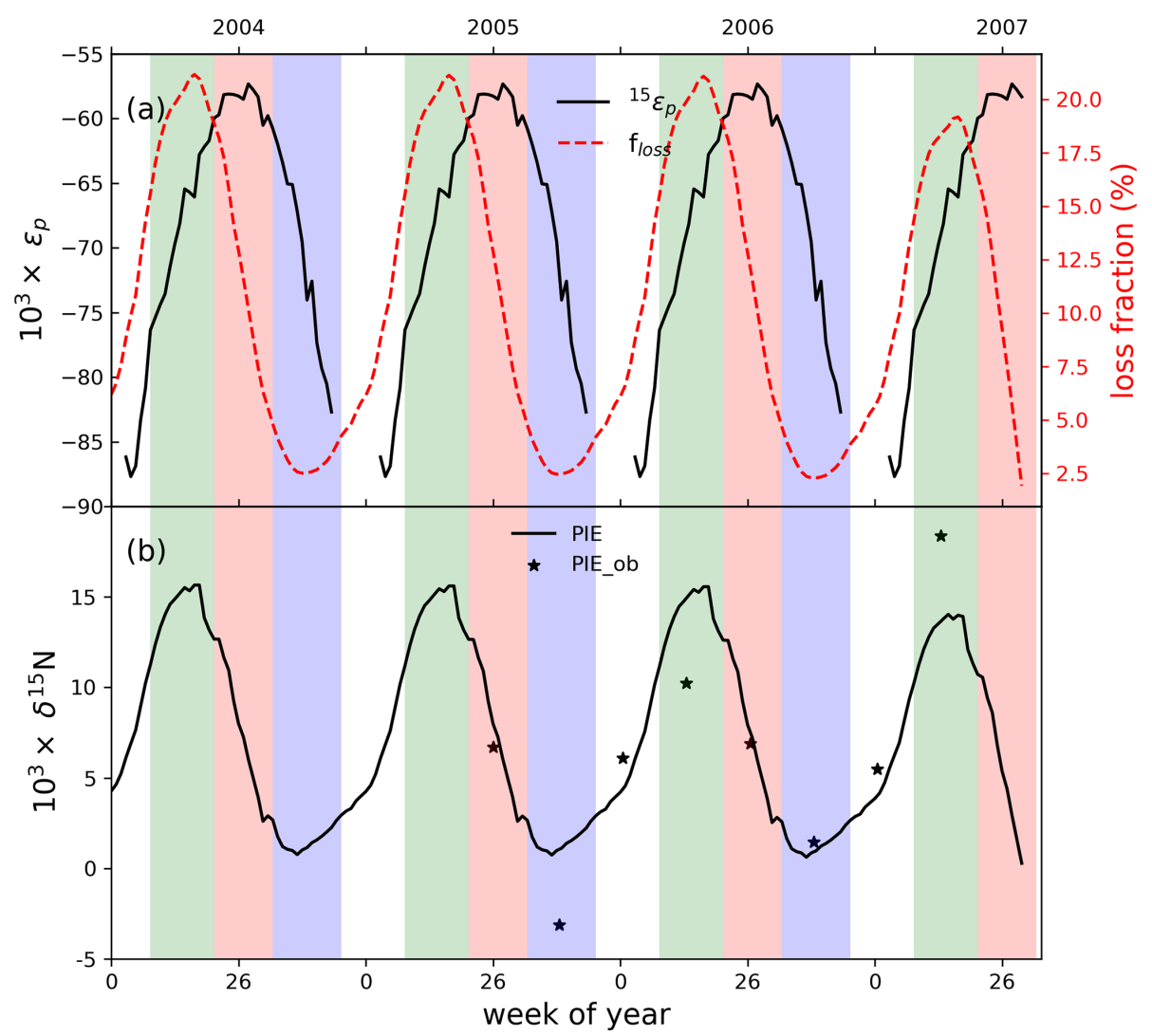

Figure 3. (a) The fraction of nitrate loss after deposition and the photolysis fractionation factor $\left(\varepsilon_{\mathrm{p}}\right)$ at different weeks. (b) PIE: the photoinduced isotope effect. The solid star represents the estimated PIE from surface and snowpack nitrate data reported by Jarvis et al. (2009). The green, red, blue and white background colors represent spring, summer, autumn and winter, respectively.

richment in snow $\delta^{15} \mathrm{~N}\left(\mathrm{NO}_{3}^{-}\right)$due to photolysis as PIE (the photo-induced isotope effect), i.e., the difference between $\delta^{15} \mathrm{~N}\left(\mathrm{NO}_{3}^{-}\right)$of a newly deposited snow layer and the same layer that was finally buried below the photic zone. As shown in Fig. 3b, PIE is the highest in the 18th week of the year, corresponding to the time of the highest $f_{\text {loss }}$. In addition, PIE displays a maximum in spring and minimum in autumn, in good agreement with the observed seasonal $\delta^{15} \mathrm{~N}\left(\mathrm{NO}_{3}^{-}\right)$ pattern in snowpack. We also estimated PIE based on the observed $\delta^{15} \mathrm{~N}\left(\mathrm{NO}_{3}^{-}\right)$in surface snow and snowpack at Summit as reported by Jarvis et al. (2009). As shown in Fig. 3b, PIE estimated based on observations (PIE_ob) agrees well with the modeled PIE. These further confirm the dominant role of the photo-driven post-depositional processing in the seasonal snowpack $\delta^{15} \mathrm{~N}\left(\mathrm{NO}_{3}^{-}\right)$pattern. Note in the model neither $f_{\text {loss }}$ nor PIE varied with seasonal differences in the flux and $\delta^{15} \mathrm{~N}$ of $F_{\text {pri }}$, respectively. The agreement between the modeled and observed PIE further demonstrates the dominant role of photo-driven post-depositional processing in seasonal $\delta^{15} \mathrm{~N}\left(\mathrm{NO}_{3}^{-}\right)$variations at Summit. Physical loss of snow nitrate through adsorption/evaporation is associated with very small $\varepsilon_{\mathrm{p}}$ (e.g., 3.6\% by Erbland et al., 2013), and given the mean summertime temperature at Summit $(261 \pm 3 \mathrm{~K})$ and a maximum lost fraction of $25 \%$ (Dibb et al., 2007), only a $\sim 1 \%$ o change in $\delta^{15} \mathrm{~N}\left(\mathrm{NO}_{3}^{-}\right)$can be caused by physical loss.

The $f_{\text {loss }}$ calculated above referred to a specific archived layer relative to when it was at the surface, and part of the loss was recycled to layers above that specific layer. Therefore, the net loss integrated over a certain period should be less than $f_{\text {loss }}$. Here we calculated an annual net loss $f_{\text {loss }}$ as follows:

$\bar{f}_{\text {loss annual }}=1-\frac{F_{\mathrm{a}}}{F_{\mathrm{pri}}}$,

where $F_{\mathrm{a}}$ represents the archival flux of nitrate $(6.33 \times$ $\left.10^{-6} \mathrm{~kg} \mathrm{~N} \mathrm{~m}^{2} \mathrm{a}^{-1}\right)$, and $\bar{f}_{\text {loss annual }}$ was calculated as $4.1 \%$. This is consistent with the annual mean $\delta^{15} \mathrm{~N}\left(\mathrm{NO}_{3}^{-}\right)$ which was $2.6 \%$ enriched compared to $\delta^{15} \mathrm{~N}$ of $F_{\text {pri. }}$. For $\Delta^{17} \mathrm{O}\left(\mathrm{NO}_{3}^{-}\right)$, upon archiving, the annual mean is $0.9 \%$ o lower than $\Delta^{17} \mathrm{O}$ of $F_{\text {pri }}$. These values represent the integrated effects of the post-depositional processing on isotopes of the archived nitrate under present Summit conditions. In addition, these results suggest that although photochemistry was active and resulted in significant redistribution of snow nitrate in the photic zone at Summit, the annual net loss is small, consistent with the results of previous studies at 
Summit based on cumulative inventory assessments of nitrate mass in snow pits (Burkhart et al., 2004; Dibb et al., 2007), as well as the result from a southeastern Greenland ice core where negligible annual nitrate loss was suggested due to the even higher snow accumulation rate $(\approx 300 \mathrm{~cm}$ snow per year) than Summit $(\approx 65 \mathrm{~cm}$ snow per year) (lizuka el al., 2018). It is also interesting to note that despite having a similar source region (Geng et al., 2015, Iizuka el al., 2018), $\delta^{15} \mathrm{~N}\left(\mathrm{NO}_{3}^{-}\right)$in this southeastern Greenland ice core is lower than in Summit ice cores (Shohei Hattori, personal communication, 2021). This is qualitatively consistent with the difference in the snow accumulation rate at the two sites since the lower snow accumulation rate at Summit will result in a higher degree of post-depositional processing.

The annual net loss in the model is mainly determined by $f_{\exp }$ which represents the fraction of exported nitrate from the site of photolysis. Although $f_{\exp }$ does not influence the loss fraction of a specific snow layer and subsequently the predicted seasonal $\delta^{15} \mathrm{~N}\left(\mathrm{NO}_{3}^{-}\right)$pattern as modeled (Fig. S3 in the Supplement), it determines how much of the reformed nitrate was recycled back to snow. In Fig. 4, we investigated the sensitivity of the annual net loss, as well as the annual mean archived $\Delta^{17} \mathrm{O}\left(\mathrm{NO}_{3}^{-}\right)$and $\delta^{15} \mathrm{~N}\left(\mathrm{NO}_{3}^{-}\right)$to $f_{\text {exp. }}$. We found the archived $\Delta^{17} \mathrm{O}\left(\mathrm{NO}_{3}^{-}\right)$decreases with increasing $f_{\text {exp }}$, while $\delta^{15} \mathrm{~N}\left(\mathrm{NO}_{3}^{-}\right)$is the opposite because larger $f_{\text {exp }}$ corresponds to less of a contribution of FP to FD. Under the extreme circumstance with $f_{\exp }=1$, i.e., all snow-sourced nitrate was exported, $\delta^{15} \mathrm{~N}\left(\mathrm{NO}_{3}^{-}\right)$in snow was on average $6.8 \%$ enriched compared to primary $F_{\text {pri }}$ under present Summit conditions, while $\Delta^{17} \mathrm{O}\left(\mathrm{NO}_{3}^{-}\right)$was only $0.2 \%$ o lower than $\Delta^{17} \mathrm{O}$ of $F_{\text {pri }}$ caused entirely by the cage effect. In this study, $f_{\exp }$ was determined to be 0.35 following the method used by Erbland et al. (2015), but this could be an underestimate. At Summit, observations by Honrath et al. (2002) indicate that $\mathrm{NO}_{x}$ and/or $\mathrm{HNO}_{3}$ emitted from sunlit snow are largely exported from the local boundary layer if no wet deposition occurs.

\subsection{Implications for interpretation of ice-core nitrate isotope records}

Due to the fast cycling of nitrate at the air-snow interface, the annual net loss $(4.1 \%)$ and the associated annual mean changes in $\delta^{15} \mathrm{~N}\left(\mathrm{NO}_{3}^{-}\right)\left(2.6 \%\right.$ o) and $\Delta^{17} \mathrm{O}\left(\mathrm{NO}_{3}^{-}\right)(0.9 \%$ o caused by post-depositional processing are small under present Summit conditions. Despite this, at seasonal scale, given the strong variations in actinic flux, post-depositional processing plays an important role in the seasonal $\delta^{15} \mathrm{~N}$ fluctuation. The degree of post-depositional processing is also strongly depending on snow accumulation rate which is usually very different in different climates. As such, the net loss and the associated isotope effects could be increased in periods with a reduced snow accumulation rate. For example, over the last glacial-interglacial period, considering only the changes in snow accumulation rate at Summit (Geng et al.,

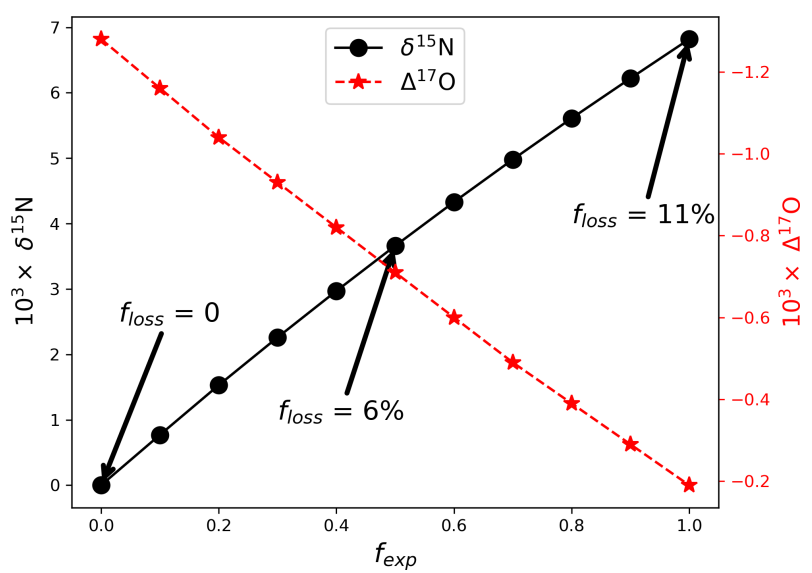

Figure 4. Sensitivity of annual mean $\delta^{15} \mathrm{~N}\left(\mathrm{NO}_{3}^{-}\right) / \Delta^{17} \mathrm{O}\left(\mathrm{NO}_{3}\right)$ upon archiving to $f_{\exp }$. Positive/negative values indicate the deviations of $F_{\text {pri }}$. Note when $f_{\text {exp }}$ is set to 1 , the small non-zero value $(-0.19 \%)$ of $\Delta^{17} \mathrm{O}\left(\mathrm{NO}_{3}^{-}\right)$represents the effects of the cage effect.

2015), the model calculated a $11 \%$ annual nitrate loss in the glacial period and a glacial-interglacial $\delta^{15} \mathrm{~N}$ difference of $9.2 \%$. In comparison, the observed glacial-interglacial $\delta^{15} \mathrm{~N}$ difference is $16.7 \pm 4.8 \%$ o (Geng et al., 2015). This suggests changes in the degree of post-depositional processing caused by the glacial-interglacial snow accumulation rate difference alone can explain more than half of the observed $\delta^{15} \mathrm{~N}\left(\mathrm{NO}_{3}^{-}\right)$ difference. Note the modeled $11 \%$ net loss in the glacial climate according to Eq. (2) is not in conflict with the $45-54 \%$ loss estimated by Geng et al. (2015), who calculated the loss fraction from $F_{\mathrm{a}}$ and FD instead of $F_{\text {pri }}$. If $F_{\text {pri }}$ in Eq. (2) is replaced with FD, the loss fraction is then $31 \%$. With the effects of changes in snow accumulation rate alone, the model predicted the glacial $\Delta^{17} \mathrm{O}\left(\mathrm{NO}_{3}^{-}\right)$would be $2 \%$ lower than in the present. This amount is significant compared to the observed glacial-interglacial $\Delta^{17} \mathrm{O}\left(\mathrm{NO}_{3}^{-}\right)$difference of $6.2 \%$ (Geng et al., 2017). Note that many other factors can influence the degree of post-depositional processing in the glacial climate, e.g., local wind speed, actinic flux, quantum yield of snow nitrate photolysis, etc., which are out of the scope of this study. But our results here reinforce the effects of post-depositional processing on ice-core nitrate concentrations and isotopes even at high snow accumulation rate sites, and such effects must be quantified and corrected in order to use ice-core nitrate records to retrieve past information on $\mathrm{NO}_{x}$ emissions and abundance and atmospheric oxidation capacity especially when the records cover different climates.

\section{Conclusions}

In this study we applied the TRANSITS model to explicitly investigate the impact of the photo-driven post-depositional processing on the preservation of nitrate and its isotopes at Summit, Greenland, with the focus on changes in nitrate iso- 
topes after deposition. The results suggest that the photodriven post-depositional processing is active at Summit, causing strong redistribution of snow nitrate accompanied by isotope effects in the photic zone. Despite the high snow accumulation rate at Summit, up to $21 \%$ loss/redistribution of nitrate can be induced by the photolysis, resulting in a spring $\delta^{15} \mathrm{~N}\left(\mathrm{NO}_{3}^{-}\right)$peak consistent with the observations. Despite uncertainties in the model, e.g., specific surface area, quantum yield of snow nitrate photolysis and the export fraction, the modeled loss/redistribution of nitrate after deposition is consistent with previous studies and explains the observed difference between $\delta^{15} \mathrm{~N}\left(\mathrm{NO}_{3}^{-}\right)$in surface snow and snow at depth. The latter is evidence of changes in $\delta^{15} \mathrm{~N}\left(\mathrm{NO}_{3}^{-}\right)$after deposition. The model also reproduced the observed seasonal patterns of snow nitrate concentration and $\delta^{15} \mathrm{~N}\left(\mathrm{NO}_{3}^{-}\right)$reasonably well, and the model-observation discrepancy in the timing of the lowest seasonal $\delta^{15} \mathrm{~N}\left(\mathrm{NO}_{3}^{-}\right)$

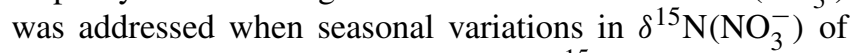
$F_{\text {pri }}$ were included. But the effects of $\delta^{15} \mathrm{~N}$ of $F_{\text {pri }}$ on snow $\delta^{15} \mathrm{~N}\left(\mathrm{NO}_{3}^{-}\right)$seasonality appear to be mainly pronounced in autumn and winter, i.e., the period with the lowest seasonal $\delta^{15} \mathrm{~N}\left(\mathrm{NO}_{3}^{-}\right)$when photolysis is negligible. This makes sense as when photolysis is muted snow nitrate $\delta^{15} \mathrm{~N}\left(\mathrm{NO}_{3}^{-}\right)$ should be the same as that of $F_{\text {pri }}$. When photolysis is active, the $\delta^{15} \mathrm{~N}\left(\mathrm{NO}_{3}^{-}\right)$signal of $F_{\text {pri }}$ is not preserved. In contrast, the post-depositional processing only led to $2.1 \%$ o seasonal change in $\Delta^{17} \mathrm{O}$. These results are consistent with the expectation that photo-driven post-depositional processing modifies $\delta^{15} \mathrm{~N}$ but has only moderate impacts on $\Delta^{17} \mathrm{O}$.

Overall, the model results suggest an important, perhaps even dominant role of post-depositional processing in regulating the snowpack $\delta^{15} \mathrm{~N}\left(\mathrm{NO}_{3}^{-}\right)$seasonality at Summit. Although the impact of photolysis of snow nitrate on $\delta^{15} \mathrm{~N}\left(\mathrm{NO}_{3}^{-}\right)$must be carefully evaluated when interpreting snowpack and ice-core nitrate isotope records even at sites with high snow accumulation rates such as Summit, Greenland, we note that this study does not address to what extent seasonal variations in $\delta^{15} \mathrm{~N}\left(\mathrm{NO}_{3}^{-}\right)$of $F_{\text {pri }}$ affect the snowpack $\delta^{15} \mathrm{~N}\left(\mathrm{NO}_{3}^{-}\right)$. Observations on the concentration and isotopic composition of $F_{\text {pri }}$ and its seasonal variations would be best to answer this question. However, it would be difficult to distinguish primary from recycled nitrate during sunlit time periods due to the local influence of snow-sourced nitrate. Additional observations including a full year or multiple years of atmospheric nitrate isotopes along with surface snow and snowpack data at a single site should be pursued in the future to fully investigate the evolution of nitrate isotopes before and after deposition, as well as to thoughtfully evaluate the effects of post-depositional processing. On the other hand, precise measurements of snowpack properties, e.g., specific surface area, impurity concentrations and observational constraints on the quantum yield of snow nitrate photolysis, and better constraints on the export fraction are also needed in order to improve the model's performance.
Code availability. The codes for the numerical simulations and their analysis will be provided upon direct request to the corresponding author.

Data availability. The model output data are available through OSF, the Open Science Framework: https://doi.org/10.17605/OSF.IO/A4B7D (Jiang et al., 2020).

Supplement. The supplement related to this article is available online at: https://doi.org/10.5194/tc-15-4207-2021-supplement.

Author contributions. LG conceived this study. ZJ performed the model simulations, analyzed the data and wrote the manuscript with LG. JE, JS and BA providing the model and helping with the model setup. All authors contributed to data interpretation and writing.

Competing interests. The authors declare that they have no conflict of interest.

Disclaimer. Publisher's note: Copernicus Publications remains neutral with regard to jurisdictional claims in published maps and institutional affiliations.

Acknowledgements. Zhuang Jiang thanks John Robinson for his assistance in starting the TRANSITS model, and we would like to thank the reviewers and the editors of the Cryosphere for their suggestions and comments to improve the manuscript. The French Polar institute (Institut Polaire Français - program SUNITEDC 1011) is thanked for field and funding support (Joel Savarino, Joseph Erbland).

Financial support. This research is funded by the National Natural Science Foundation of China (Awards: 41822605, 41871051 and 41727901), the Fundamental Research Funds for Central Universities, the Strategic Priority Research Program of Chinese Academy of Sciences (grant no. XDB 41000000), and the National Key R\&D Program of China (grant nos. 2019YFC1509100 and 2016YFA0302200). Support for Joel Savarino and Joseph Erbland was provided by the French national programme LEFE/INSU and the ANR grants ANR-15-IDEX-02 (project IDEX Universite Grenoble Alpes) and ANR-16-CE01-0011-01 (EAIIST project) of the French Agence Nationale de la Recherche. Becky Alexander was supported by the NSF (grant no. PLR 1542723).

Review statement. This paper was edited by Florent Dominé and reviewed by two anonymous referees. 


\section{References}

Alexander, B. and Mickley, L. J.: Paleo-perspectives on potential future changes in the oxidative capacity of the atmosphere due to climate change and anthropogenic emissions, Current Pollution Reports, 1, 57-69, https://doi.org/10.1007/s40726-015-0006-0, 2015.

Alexander, B., Savarino, J., Kreutz, K. J., and Thiemens, M.: Impact of preindustrial biomass-burning emissions on the oxidation pathways of tropospheric sulfur and nitrogen, J. Geophys. Res.Atmos., 109, D08303, https://doi.org/10.1029/2003JD004218, 2004.

Alexander, B., Sherwen, T., Holmes, C. D., Fisher, J. A., Chen, Q., Evans, M. J., and Kasibhatla, P.: Global inorganic nitrate production mechanisms: comparison of a global model with nitrate isotope observations, Atmos. Chem. Phys., 20, 3859-3877, https://doi.org/10.5194/acp-20-3859-2020, 2020.

Atkinson, R., Baulch, D. L., Cox, R. A., Crowley, J. N., Hampson, R. F., Hynes, R. G., Jenkin, M. E., Rossi, M. J., and Troe, J.: Evaluated kinetic and photochemical data for atmospheric chemistry: Volume $\mathrm{I}-$ gas phase reactions of $\mathrm{O}_{x}, \mathrm{HO}_{x}$, $\mathrm{NO}_{x}$ and $\mathrm{SO}_{x}$ species, Atmos. Chem. Phys., 4, 1461-1738, https://doi.org/10.5194/acp-4-1461-2004, 2004. z

Berhanu, T. A., Meusinger, C., Erbland, J., Jost, R., Bhattacharya, S., Johnson, M. S., and Savarino, J.: Laboratory study of nitrate photolysis in Antarctic snow. II. Isotopic effects and wavelength dependence, J. Chem. Phys., 140, 244306, https://doi.org/10.1063/1.4882899, 2014.

Björkman, M., Kühnel, R., Partridge, D., Roberts, T., Aas, W., Mazzola, M., Viola, A., Hodson, A., Ström, J., and Isaksson, E.: Nitrate dry deposition in Svalbard, Tellus B, 65, 19071, https://doi.org/10.3402/tellusb.v65i0.19071, 2013.

Blunier, T., Floch, G. L., Jacobi, H. W., and Quansah, E.: Isotopic view on nitrate loss in Antarctic surface snow, Geophys. Res. Lett., 32, L13501, https://doi.org/10.1029/2005GL023011, 2005.

Burkhart, J. F., Hutterli, M., Bales, R. C., and McConnell, J. R.: Seasonal accumulation timing and preservation of nitrate in firn at Summit, Greenland, J. Geophys. Res.-Atmos., 109, D22309, https://doi.org/10.1029/2004JD004658, 2004.

Carmagnola, C. M., Domine, F., Dumont, M., Wright, P., Strellis, B., Bergin, M., Dibb, J., Picard, G., Libois, Q., Arnaud, L., and Morin, S.: Snow spectral albedo at Summit, Greenland: measurements and numerical simulations based on physical and chemical properties of the snowpack, The Cryosphere, 7, 1139-1160, https://doi.org/10.5194/tc-7-1139-2013, 2013.

Chu, L. and Anastasio, C.: Quantum yields of hydroxyl radical and nitrogen dioxide from the photolysis of nitrate on ice, J. Phys Chem., 107, 9594-9602, 2003.

Cohen, L., Helmig, D., Neff, W. D., Grachev, A. A., and Fairall, C. W.: Boundary-layer dynamics and its influence on atmospheric chemistry at Summit, Greenland, Atmos. Environ., 41, 5044-5060, https://doi.org/10.1016/j.atmosenv.2006.06.068, 2007.

Curtis, C. J., Kaiser, J., Marca, A., Anderson, N. J., Simpson, G., Jones, V., and Whiteford, E.: Spatial variations in snowpack chemistry, isotopic composition of $\mathrm{NO}_{3}^{-}$and nitrogen deposition from the ice sheet margin to the coast of western Greenland, Biogeosciences, 15, 529-550, https://doi.org/10.5194/bg15-529-2018, 2018.
Dibb, J. E. and Fahnestock, M.: Snow accumulation, surface height change, and firn densification at Summit, Greenland: Insights from 2 years of in situ observation, J. Geophys. Res.-Atmos., 109, D24113, https://doi.org/10.1029/2003JD004300, 2004.

Dibb, J. E., Arsenault, M., Peterson, M. C., and Honrath, R. E.: Fast nitrogen oxide photochemistry in Summit, Greenland snow, Atmos. Environ, 36, 2501-2511, https://doi.org/10.1016/S13522310(02)00130-9, 2002.

Dibb, J. E., Whitlow, S. I., and Arsenault, M.: Seasonal variations in the soluble ion content of snow at Summit. Greenland: Constraints from three years of daily surface snow samples, Atmos. Environ., 41, 5007-5019, https://doi.org/10.1016/j.atmosenv.2006.12.010, 2007.

Domine, F., Taillandier, A. S., and Simpson, W. R.: A parameterization of the specific surface area of seasonal snow for field use and for models of snowpack evolution, J. Geophys. Res.-Earth, 112, F02031, https://doi.org/10.1029/2006JF000512, 2007.

Erbland, J., Vicars, W. C., Savarino, J., Morin, S., Frey, M. M., Frosini, D., Vince, E., and Martins, J. M. F.: Air-snow transfer of nitrate on the East Antarctic Plateau - Part 1: Isotopic evidence for a photolytically driven dynamic equilibrium in summer, Atmos. Chem. Phys., 13, 6403-6419, https://doi.org/10.5194/acp13-6403-2013, 2013.

Erbland, J., Savarino, J., Morin, S., France, J. L., Frey, M. M., and King, M. D.: Air-snow transfer of nitrate on the East Antarctic Plateau - Part 2: An isotopic model for the interpretation of deep ice-core records, Atmos. Chem. Phys., 15, 12079-12113, https://doi.org/10.5194/acp-15-12079-2015, 2015.

Fibiger, D. L., Hastings, M. G., Dibb, J. E., and Huey, L. G.: The preservation of atmospheric nitrate in snow at Summit, Greenland, Geophys. Res. Lett., 40, 3484-3489, https://doi.org/10.1002/grl.50659, 2013.

Fibiger, D. L., Dibb, J. E., Chen, D., Thomas, J. L., Burkhart, J. F., Huey, L. G., and Hastings, M. G.: Analysis of nitrate in the snow and atmosphere at Summit, Greenland: Chemistry and transport, J. Geophys. Res.-Atmos., 121, 5010-5030, https://doi.org/10.1002/2015JD024187, 2016.

Frey, M. M., Savarino, J., Morin, S., Erbland, J., and Martins, J. M. F.: Photolysis imprint in the nitrate stable isotope signal in snow and atmosphere of East Antarctica and implications for reactive nitrogen cycling, Atmos. Chem. Phys., 9, 8681-8696, https://doi.org/10.5194/acp-9-8681-2009, 2009.

Freyer, H. D., Kobel, K., Delmas, R. J., Kley, D., and Legrand, M. R.: First results of ${ }^{15} \mathrm{~N} /{ }^{14} \mathrm{~N}$ ratios in nitrate from alpine and polar ice cores, Tellus, 48, 93-105, https://doi.org/10.1034/j.1600-0889.1996.00009.x, 1996.

Galbavy, E. S., Anastasio, C., Lefer, B. L., and Hall, S. R.: Light penetration in the snowpack at Summit, Greenland: Part 1: Nitrite and hydrogen peroxide photolysis, Atmos. Environ., 41, 50775090, https://doi.org/10.1016/j.atmosenv.2006.04.072, 2007.

Geng, L., Alexander, B., Cole-Dai, J., Steig, E. J., Savarino, J., Sofen, E. D., and Schauer, A. J.: Nitrogen isotopes in ice core nitrate linked to anthropogenic atmospheric acidity change, P. Natl. Acad. Sci. USA, 111, 5808-5812. https://doi.org/10.1073/pnas.1319441111, 2014a.

Geng, L., Cole-Dai, J., Alexander, B., Erbland, J., Savarino, J., Schauer, A. J., Steig, E. J., Lin, P., Fu, Q., and Zatko, M. C.: On the origin of the occasional spring nitrate peak 
in Greenland snow, Atmos. Chem. Phys., 14, 13361-13376, https://doi.org/10.5194/acp-14-13361-2014, 2014b.

Geng, L., Zatko, M. C., Alexander, B., Fudge, T., Schauer, A. J., Murray, L. T., and Mickley, L. J.: Effects of postdepositional processing on nitrogen isotopes of nitrate in the Greenland Ice Sheet Project 2 ice core, Geophys. Res. Lett., 42, 5346-5354, https://doi.org/10.1002/2015GL064218, 2015.

Geng, L., Murray, L. T., Mickley, L. J., Lin, P., Fu, Q., Schauer, A. J., and Alexander, B.: Isotopic evidence of multiple controls on atmospheric oxidants over climate transitions, Nature, 546, 133-136, https://doi.org/10.1038/nature22340, 2017.

Goto-Azuma, K. and Koerner, R. M.: Ice core studies of anthropogenic sulfate and nitrate trends in the Arctic, J. Geophys. Res.-Atmos., 106, 4959-4969, https://doi.org/10.1029/2000JD900635, 2001.

Hastings, M., Jarvis, J., and Steig, E.: Anthropogenic impacts on nitrogen isotopes of ice-core nitrate, Science, 324, 1288-1288, https://doi.org/10.1126/science.1170510, 2009.

Hastings, M. G., Steig, E., and Sigman, D. M.: Seasonal variations in $\mathrm{N}$ and $\mathrm{O}$ isotopes of nitrate in snow at Summit, Greenland: Implications for the study of nitrate in snow and ice cores, J. Geophys. Res.-Atmos., 109, D20306, https://doi.org/10.1029/2004JD004991, 2004.

Hastings, M. G., Sigman, D. M., and Steig, E. J.: Glacial/interglacial changes in the isotopes of nitrate from the Greenland Ice Sheet Project 2 (GISP2) ice core, Global Biogeochem. Cy., 19, GB4024, https://doi.org/10.1029/2005GB002502, 2005.

Honrath, R., Lu, Y., Peterson, M. C., Dibb, J. E., Arsenault, M., Cullen, N., and Steffen, K.: Vertical fluxes of $\mathrm{NO}_{x}, \mathrm{HONO}$, and $\mathrm{HNO}_{3}$ above the snowpack at Summit, Greenland, Atmos. Environ., 36, 2629-2640, https://doi.org/10.1016/S13522310(02)00132-2, 2002.

Iizuka, Y., Uemura, R., Fujita, K., Hattori, S., Seki, O., Miyamoto, C., Suzuki, T., Yoshida, N., Motoyama, H., and Matoba, S: A 60 Year Record of Atmospheric Aerosol Depositions Preserved in a High-Accumulation Dome Ice Core, Southeast Greenland, J. Geophys. Res.-Atmos., 123, 574-589, https://doi.org/10.1002/2017JD026733, 2018.

Jarvis, J. C., Hastings, M. G., Steig, E. J., and Kunasek, S. A.: Isotopic ratios in gas-phase $\mathrm{HNO}_{3}$ and snow nitrate at Summit, Greenland, J. Geophys. Res.-Atmos., 114, D17301, https://doi.org/10.1029/2009JD012134, 2009.

Jiang, Z.: TRANSITS Simulation Results on Summit Snow, OSF [data set], https://doi.org/10.17605/OSF.IO/A4B7D, 2020.

Kukui, A., Legrand, M., Preunkert, S., Frey, M. M., Loisil, R., Gil Roca, J., Jourdain, B., King, M. D., France, J. L., and Ancellet, G.: Measurements of $\mathrm{OH}$ and $\mathrm{RO}_{2}$ radicals at Dome C, East Antarctica, Atmos. Chem. Phys., 14, 12373-12392, https://doi.org/10.5194/acp-14-12373-2014, 2014.

Kunasek, S., Alexander, B., Steig, E., Hastings, M., Gleason, D., and Jarvis, J.: Measurements and modeling of $\Delta^{17} \mathrm{O}$ of nitrate in snowpits from Summit, Greenland, J. Geophys. Res.-Atmos., 113, D24302, https://doi.org/10.1029/2008JD010103, 2008.

Legrand, M. R. and Delmas, R. J.: Relative contributions of tropospheric and stratospheric sources to nitrate in Antarctic snow, Tellus B, 38, 236-249, https://doi.org/10.3402/tellusb.v38i34.15132, 1986.

Liao, J., Huey, L. G., Tanner, D. J., Brough, N., Brooks, S., Dibb, J. E., Stutz, J., Thomas, J. L., Lefer, B., Haman, C., and Gorham,
K.: Observations of hydroxyl and peroxy radicals and the impact of BrO at Summit, Greenland in 2007 and 2008, Atmos. Chem. Phys., 11, 8577-8591, https://doi.org/10.5194/acp11-8577-2011, 2011.

Libois, Q., Picard, G., France, J. L., Arnaud, L., Dumont, M., Carmagnola, C. M., and King, M. D.: Influence of grain shape on light penetration in snow, The Cryosphere, 7, 1803-1818, https://doi.org/10.5194/tc-7-1803-2013, 2013.

Madronich, S., McKenzie, R. L., Björn, L. O., and Caldwell, M. M.: Changes in biologically active ultraviolet radiation reaching the Earth's surface, J. Photoch. Photobio. B, 46, 5-19, https://doi.org/10.1016/S1011-1344(98)00182-1, 1998.

McCabe, J., Boxe, C., Colussi, A., Hoffmann, M., and Thiemens, M.: Oxygen isotopic fractionation in the photochemistry of nitrate in water and ice, J. Geophys. Res.-Atmos., 110, D15310, https://doi.org/10.1029/2004JD005484, 2005.

Meusinger, C., Berhanu, T. A., Erbland, J., Savarino, J., and Johnson, M. S.: Laboratory study of nitrate photolysis in Antarctic snow. I. Observed quantum yield, domain of photolysis, and secondary chemistry, J. Chem. Phys., 140, 244305, https://doi.org/10.1063/1.4882898, 2014.

Morin, S., Savarino, J., Frey, M. M., Yan, N., Bekki, S., Bottenheim, J. W., and Martins, J. M.: Tracing the origin and fate of $\mathrm{NO}_{x}$ in the Arctic atmosphere using stable isotopes in nitrate, Science, 322, 730-732, https://doi.org/10.1126/science.1161910, 2008.

Noro, K., Hattori, S., Uemura, R., Fukui, K., Hirabayashi, M., Kawamura, K., Motoyama, H., Takenaka, N., and Yoshida, N.: Spatial variation of isotopic compositions of snowpack nitrate related to post-depositional processes in eastern Dronning Maud Land, East Antarctica, Geochem. J., 52, e7-e14, https://doi.org/10.2343/geochemj.2.0519, 2018.

Shi, G., Buffen, A. M., Hastings, M. G., Li, C., Ma, H., Li, Y., Sun, B., An, C., and Jiang, S.: Investigation of post-depositional processing of nitrate in East Antarctic snow: isotopic constraints on photolytic loss, re-oxidation, and source inputs, Atmos. Chem. Phys., 15, 9435-9453, https://doi.org/10.5194/acp15-9435-2015, 2015.

Sjostedt, S. J., Huey, L. G., Tanner, D. J., Peischl, J., Chen, G., Dibb, J. E., Lefer, B., Hutterli, M. A., Beyersdorf, A. J., Blake, N. J., Blake, D. R., Sueper, D., Ryerson, T., Burkhart, J., and Stohl, A.: Observations of hydroxyl and the sum of peroxy radicals at Summit, Greenland during summer 2003, Atmos. Environ., 41, 5122 5137, https://doi.org/10.1016/j.atmosenv.2006.06.065, 2007.

Thomas, J. L., Dibb, J. E., Huey, L. G., Liao, J., Tanner, D., Lefer, B., von Glasow, R., and Stutz, J.: Modeling chemistry in and above snow at Summit, Greenland - Part 2: Impact of snowpack chemistry on the oxidation capacity of the boundary layer, Atmos. Chem. Phys., 12, 6537-6554, https://doi.org/10.5194/acp12-6537-2012, 2012.

Vicars, W. C. and Savarino, J.: Quantitative constraints on the ${ }^{17} \mathrm{O}$-excess $\left(\Delta^{17} \mathrm{O}\right)$ signature of surface ozone: Ambient measurements from $50^{\circ} \mathrm{N}$ to $50^{\circ} \mathrm{S}$ using the nitrite-coated filter technique, Geochim. Cosmochim. Ac., 135, 270-287, https://doi.org/10.1016/j.gca.2014.03.023, 2014.

Wolff, E. W., Jones, A. E., Bauguitte, S. J.-B., and Salmon, R. A.: The interpretation of spikes and trends in concentration of nitrate in polar ice cores, based on evidence from snow and at- 
mospheric measurements, Atmos. Chem. Phys., 8, 5627-5634, https://doi.org/10.5194/acp-8-5627-2008, 2008.

Zatko, M., Geng, L., Alexander, B., Sofen, E., and Klein, K.: The impact of snow nitrate photolysis on boundary layer chemistry and the recycling and redistribution of reactive nitrogen across Antarctica and Greenland in a global chemical transport model, Atmos. Chem. Phys., 16, 2819-2842, https://doi.org/10.5194/acp-16-2819-2016, 2016.
Zatko, M. C., Grenfell, T. C., Alexander, B., Doherty, S. J., Thomas, J. L., and Yang, X.: The influence of snow grain size and impurities on the vertical profiles of actinic flux and associated $\mathrm{NO}_{x}$ emissions on the Antarctic and Greenland ice sheets, Atmos. Chem. Phys., 13, 3547-3567, https://doi.org/10.5194/acp13-3547-2013, 2013. 